\title{
The effect of ECB communication on interest rates: An assessment
}

\author{
Jakob De Haan
}

Received: 29 February 2008 /Revised: 13 August 2008 / Accepted: 25 September 2008 / Published online: 29 October 2008

C The Author(s) 2008. This article is published with open access at Springerlink.com

\begin{abstract}
This paper reviews the literature on the communication policy of the European Central Bank (ECB) addressing two questions. First, to what extent has ECB communication affected interest rates? Second, to what extent has ECB communication affected the predictability of the ECB's interest rate decisions? On the basis of a survey of empirical studies, it is concluded that various forms of ECB communication lead to more volatility. However, studies focusing on volatility cannot assess whether markets moved in the intended direction. To analyze whether this is the case, researchers have coded ECB communications. Studies using this approach yield evidence that communications generally move financial markets in the intended direction. There is also substantive evidence that ECB communications increase the predictability of interest decisions by the ECB Governing Council. Finally, the consequences of the fact that ECB officials often gave contrasting signals to market participants are analyzed. New evidence suggests that inconsistent communication causes agents to make less accurate predictions. The policy implication is that central bankers should take care that their statements are consistent.
\end{abstract}

Keywords Central bank communication $\cdot$ ECB

\section{JEL Classification E43 E52 E58}

"Our keen preoccupation with making ourselves understood by words and deeds has established a new climate of mutual understanding with academics, investors, market participants and public opinion at large.” (Trichet 2005)

Electronic Supplementary Material The online version of this article (doi:10.1007/s11558-008-9048-z) contains supplementary material, which is available to authorized users.

J. De Haan $(\bowtie)$

Faculty of Economics and Business, University of Groningen, P.O. Box 800, 9700 AV Groningen, The Netherlands

e-mail: jakob.de.haan@rug.nl

J. De Haan

CESifo, Munich, Germany 


\section{Introduction}

Since monetary policy is increasingly becoming the art of managing expectations, communication has developed into a key instrument in the central bankers' toolbox in recent years. There is only a single tool (the overnight interest rate) that can be used by central banks to exert an (indirect) effect on those asset prices that are of key importance for the economy, such as long-term interest rates, equity prices, and exchange rates. Communication, therefore, provides an important means for central banks to influence these asset prices. First, communication may be used to guide private sector expectations. As such, it plays an important role in improving the effectiveness of policy and, in the end, the economy's overall performance. Trichet (2005) even states: "under some conditions the central bank can regain control of private expectations without necessarily changing interest rates, but by being visibly and credibly "alert," explaining and stressing its commitment to maintaining inflation at levels consistent with the price stability objective. The threat to act will be more effective the more credible the central bank has been over time in actually delivering price stability, as defined quantitatively."

Second, communication may be used to reduce noise in financial markets. Greater disclosure and clarity over policy may lead to greater predictability of central bank actions, which, in turn, reduces uncertainty in financial markets. There is a stronglyheld belief among central bankers nowadays that a high degree of predictability is important. As Poole (2001, p. 9) put it: "The presumption must be that market participants make more efficient decisions... when markets can correctly predict central bank actions."

The extent to which central bank communication has been successful is very much an empirical issue. Therefore, it is no surprise that the empirical literature on communication has seen major developments in recent years. This paper reviews the literature on the communication policy of the European Central Bank (ECB). We ask two questions. First, to what extent has ECB communication affected interest rates? Second, to what extent has ECB communication affected the predictability of the ECB's interest rate decisions?

In addressing these questions, we survey studies focusing on the impact of the ECB's communication on interest rates and the predictability of policy decisions. ${ }^{1}$ We start by identifying why central bank communication may affect financial markets. To assess the impact of ECB communication empirically, authors have come up with various indicators of ECB communication. As part of our discussion of the literature, we compare these indicators. We conclude that there are substantial differences across these indicators. Despite these differences, it turns out that there is quite some evidence suggesting that ECB communication affects interest rates (and also some other asset prices). Likewise, most research concludes that ECB communication has increased the predictability of monetary policy. However, we point out that communication may also hamper to correctly predict policy decisions due to what we call communication dispersion. Central bank talk is not always

\footnotetext{
${ }^{1}$ We do not discuss studies like those of Fratzscher (2004), Jansen and De Haan (2005, 2007a), Siklos and Bohl (2006) and Conrad and Lamla (2007) that focus on the impact of ECB communication on the eurodollar exchange rate.
} 
consistent: ECB officials often gave contrasting signals to market participants. These diverging signals were related to various aspects of monetary policy, such as the policy inclination, or the economic outlook. It is likely that this dispersion affects the ability of market participants to correctly predict monetary policy decisions (Jansen and De Haan 2006). ${ }^{2}$ We present new evidence on the impact of communication dispersion, following a similar approach as Ehrman and Fratzscher (2005) and using a unique dataset of statements made by euro area central bankers during the first years of the European Economic and Monetary Union (EMU). This period is interesting as both the ECB and financial markets had to learn how to deal with communication by a newly created international organization.

The paper is structured as follows. The next section outlines why central bank communication may affect financial markets. Section 3 briefly describes the ECB's communication policies and Section 4 discusses various indicators of ECB communication. Section 5 reviews empirical work assessing whether ECB communications have affected interest rates and the predictability of policy decisions. Section 6 presents new evidence on the impact of communication dispersion on the predictability of ECB policy decisions. Finally, Section 7 offers some concluding comments.

\section{Why Does Central Bank Communication Matter?}

Central bank communication can be defined as the provision of information by the central bank to the public on the objectives of monetary policy, the monetary policy strategy, the economic outlook, and (the outlook for future) policy decisions.

It is widely accepted that nowadays the ability of central banks to affect the economy critically depends upon their ability to influence market expectations regarding the future path of overnight interest rates, and not merely their current level. Therefore, the public's understanding of current and future policy is critical for the effectiveness of policy. Still, it is not obvious that communication may help the central bank realizing its ultimate objective(s), like price stability and stable economic growth. From a theoretical point of view, communication has little value added if the central bank credibly commits to a policy rule. Assuming that the public has rational expectations, any systematic pattern in the way that policy is conducted should be correctly inferred from the central bank's observed behaviour (Woodford 2005). Thus, when it comes to predicting future interest rates, it suffices to interpret (forecasts of) economic data in view of the central bank's policy rule; there is no need for central bank communication. Following Faust and Svensson's (2001, p. 373) definition of central bank transparency-i.e., how easily the public can deduce central-bank goals and intentions from 'observables' - one might say that a central bank can be fully transparent without any communication.

This stylized example makes clear that there are, essentially, three conditions under which central bank communication may matter: non-rational expectations,

\footnotetext{
${ }^{2}$ Indeed, Ehrmann and Fratzscher (2007b) find for three central banks (the Federal Reserve, the ECB, and the Bank of England) that a higher degree of dispersion in communication lowered the predictability of their policy decisions (as measured by the difference between actual and expected decisions).
} 
absence of policy rules and credibility, and asymmetric information. If one or more of these conditions hold, central bank communication may have an impact on the economy.

First, the assumption that the public will understand monetary policy perfectly regardless of the efforts that are made to explain it may be unrealistic. Woodford (2005, p. 403) argues that: "Insofar as explanation of the policy rule to the public does no harm under the assumption of rational expectations, but improves outcomes under the (more realistic) assumption that a correct understanding of the central bank's policy commitments does not occur automatically, then it is clearly desirable for the central bank to explain the rule that it follows."

King (2005) goes even further and argues that the public may follow simple (but possibly fairly robust) 'heuristics' in making decisions instead of following optimizing behaviour. He argues that in this case central bank communication can play an important role in leading people to choose heuristics of the right sort: "the more the central bank can do to behave in a way that makes it easy for the private sector to adopt a simple heuristic to guide expectations the better. A good heuristic from that point of view would be "expect inflation to be equal to target"' (King 2005, p. 12). In other words, by communicating to the public the central bank may help anchoring expectations.

Second, most central banks do not follow a fixed rule. For example, ECB president Jean-Claude Trichet has repeatedly stressed that the ECB takes its decisions one step at a time. In the Q\&A session after the interest rate decision on 2 March 2006, Trichet said: "We do not engage a priori in a series of interest rate hikes...we do not pre-commit ourselves unconditionally."

Third, financial-market participants generally do not have as much information as monetary policymakers do about a number of key inputs to policymaking, including the policymakers' objectives, their assessment of the economic situation, and their policy strategy. If there is asymmetric information, i.e., if the public and the central bank dispose of different information, it may be perfectly rational for the public to adjust their expectations if the central bank provides new information. Here we should distinguish between the type of information that is provided by the central bank.

The central bank may provide information about its reaction function. This should lead, ceteris paribus, to an increase in the private sector's ability to forecast the central bank's policy decisions. Suppose, the central bank follows a Taylor-type rule,

$$
r_{t}=r^{*}+\pi_{t}+\alpha y_{t}+\beta\left(\pi_{t}-\pi^{*}\right)
$$

where $r, r^{*}, y, \pi$ and $\pi^{*}$ denote the interest rate, the target interest rate, the output gap, inflation and target inflation, respectively. An improvement in the private sector's understanding of what values the central bank uses for $r^{*}, \pi^{*}, \alpha$ and $\beta$ would lead to improved private sector forecasts for $r_{t}$ (Swanson 2006). One possibility in countries without explicit inflation targets is that the central bank may provide information about its long-run inflation target (Kohn and Sack 2004). Likewise, central banks could also provide information on the relative weights that the central bank places on its output and inflation objectives. The parameter $\alpha$ is an important determinant of the speed with which policy seeks to put inflation back on target following adverse shocks. The larger is $\alpha$, the larger is the "flexibility" allowed in returning to the inflation target 
following a shock. Hence, it determines the period-by-period deviations of inflation from its target. Providing this kind of information may help the private sector to form more accurate expectations. According to Trichet (2005), "If the central bank is able to convince economic agents and markets participants of its analysis and assessment of the outlook, and about the policy measures that it is going to take in response to it, this mechanism of anticipation will act in self-equilibrating manner. As soon as the macroeconomic news is released, expectations of the short-term interest rates will adjust in the equilibrating direction that markets expect to see implemented by the central bank."

Bernanke (2004) refers to the recent literature on adaptive learning in explaining why communication on these issues affects monetary policy effectiveness (see Blinder et al. 2008 for a further discussion). When the public does not know but instead must estimate the central bank's reaction function, there is no guarantee that the economy will converge to the optimal rational expectations equilibrium because the public's learning process itself affects the behaviour of the economy. The feedback effect of learning on the economy can lead to unstable or indeterminate outcomes. In such a setting, communication by the central bank may play a key role in helping improve economic performance.

Furthermore, the central bank may have better information on the economic outlook. ${ }^{3}$ Various studies find that financial markets not only react to macroeconomic news (e.g. Balduzzi et al. 2001 for the case of the USA), but also to information on the economic outlook provided by the central bank. Apparently investors update their own views in response to the information conveyed by the central bank. Kohn and Sack (2004) argue that private agents may lend special credence to the economic pronouncements of the central bank, particularly if the central bank has established credibility as an effective forecaster of the economy. They point out that the Federal Reserve has been broadly correct on the direction of the economy and prices over the past two decades, on occasion spotting trends and developments before they were evident to market participants. This record has enhanced its reputation and credibility. ${ }^{4}$

Even though there are good reasons why communication may be beneficial, it is by no means clear what constitutes an optimal communication strategy. The literature on central bank transparency has shown that full disclosure of all available information is often not optimal. Unfortunately, the theoretical literature has not come up with clear-cut conclusions regarding the optimal level of transparency (Geraats 2002). In general, the central bank faces a trade-off when there are limits as to how much information can be digested effectively (Kahnemann 2003). The tradeoff might become even more pronounced if the central bank communicates about

\footnotetext{
${ }^{3}$ One of the referees suggested another difference, namely the asymmetry in the treatment of macroeconomic information. Market participants have a monitoring horizon biased toward short-term movements of financial markets, while the central bank analyzes every kind of economic development and their short to medium-term impact on inflation and economic activity. As a consequence, market participants have a limited ability to build proper data-driven economic scenarios consistent with the central bank's view of future inflation. Communication may help them forming a better view.

${ }^{4}$ Romer and Romer (2000) provide statistical evidence that the Federal Reserve staff forecasts for output and inflation have been more accurate than private sector forecasts over the past several decades.
} 
issues on which it receives noisy signals itself, such as the evolution of the economy (as opposed to, e.g., its intentions regarding upcoming interest rate decisions). This has been stressed by Amato et al. (2002) who argue that central bank communication can co-ordinate the actions of financial market participants away from fundamentals, in the sense that they attach too much weight to the central bank's views, not taking into account that they reflect a noisy signal. Blinder et al. (2008) present arguments casting doubts on the validity of this argument.

\section{The ECB's Communication Policy}

Central banks communicate about at least four different aspects of monetary policy: their overall objectives and strategy, the motives behind a particular policy decision, the economic outlook, and future monetary policy decisions. Central banks can choose from a large menu of communication instruments, like press conferences, minutes of the meetings of the decision-making council, monthly bulletins, speeches and interviews.

The ECB mainly relies on four communication devices. The ECB's most important communication device is the President's introductory statement at the monthly press conference in which he reports on the decisions taken by the ECB's Governing Council. Following meetings of the Council, which typically take place on the first Thursday of each month, the ECB announces the monetary policy decisions at 13:45 (CET). Some $45 \mathrm{~min}$ later, at around 14:30, the ECB President and Vice-President hold a press conference that comprises two elements: a prepared introductory statement that contains the background considerations for the monetary policy decision, and a Questions \& Answers (Q\&A) part during which the President and the Vice-President are available to answer questions by the attending journalists. The introductory statement is understood to reflect the position and views of the Council, agreed upon on a word-by-word basis by its members. While providing background information on the rationale for its decision, the ECB press conference is generally less detailed than the minutes of the Bank of England or the Federal Reserve (Blinder et al. 2008). In particular, it does not provide any information on voting. However, the press conference avoids the substantial time delay of the minutes. Furthermore, the Q\&A session allows the press to ask follow-up questions and thus can help clarify open issues (Ehrmann and Fratzscher 2007a).

A second important communication device for the ECB is its Monthly Bulletin, which is published 1 week after each monetary policy meeting and contains both the assessment of economic developments and information on its analytical frameworke.g., models, methods and indicators - used in the decision-making process. The editorial of the Bulletin contains a short explanation of the interest rate decision of the previous month and frequently includes a summary statement of the Governing Council's view of the economy.

The testimonies of the ECB President (or sometimes of other Executive Board members) to the European Parliament (EP) offer also an opportunity to communicate. Four times a year, the President appears before the EP's Committee on Economic and Monetary Affairs and explains the ECB's policy decisions and its economic outlook. Subsequently, he answers questions posed by Committee 


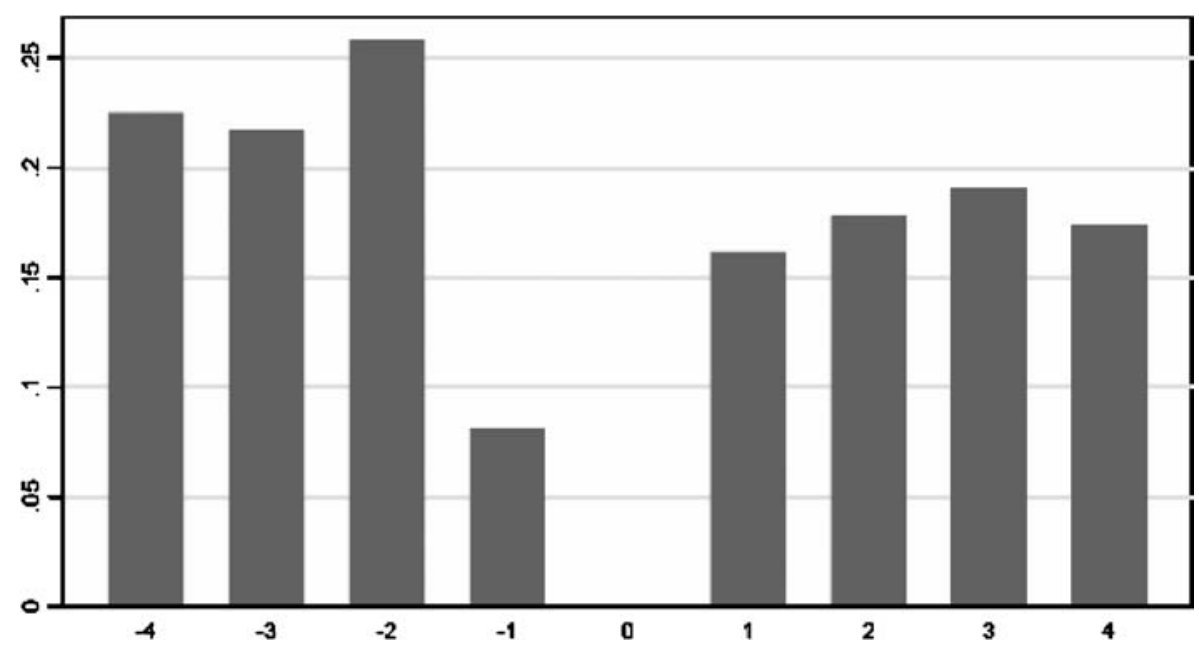

Fig. 1 The timing of ECB communication. Notes: The vertical axis indicates the fraction of days in which communication takes place. The bars aggregate data from 2 days (i.e., bar "-1" contains days 2 and 1 before a meeting of the decision-making body). The first and last bars additionally contain 22 observations on days beyond \pm 8 . Source: Ehrmann and Fratzscher (2007c)

members. These testimonies are open to the public and the transcripts of the presentations are published on the websites of both the EP and the ECB.

Finally, ECB officials often give speeches or interviews on monetary policy making. Communications by individual central bankers offer greater flexibility in timing than pre-scheduled events. ${ }^{5}$ Occasional speeches and interviews by individual committee members between meetings offer a way to communicate changes in views rapidly, if so desired (Blinder et al. 2008). Furthermore, in the case of the ECB, national central banks feel they are responsible for explaining ECB policies to their respective national audiences.

Ehrmann and Fratzscher (2007c) have analyzed the timing of communication by individual ECB Governing Board members. Figure 1, which is reproduced from this study, shows that except for days surrounding the monetary policy meetings, there is a somewhat higher level of activity before than after meetings (which is statistically significant at the 5\% level), stressing the attempt of the ECB to prepare markets for the upcoming meeting. Ehrmann and Fratzscher also find that when a policy surprise is large (i.e., when its absolute value is above the average absolute surprise) ECB officials are more talkative. Whereas the members of the Governing Council normally talk to the public roughly every 7 (business) days, they do so more than every 5 days if there has been a large surprise at the previous meeting.

When it comes to likely future policy decisions, many central banks provide some sort of forward guidance, albeit in very different ways (see Blinder et al. 2008 for

\footnotetext{
${ }^{5}$ Ehrmann and Fratzscher (2007b) report that $62.2 \%$ of communications on the monetary policy inclination by individual ECB central bankers were in line with the next policy decision, while $82.3 \%$ of these communications were in line with the next policy change.
} 
further details). ${ }^{6}$ The ECB uses indirect signals, often in the form of code words like 'vigilance.' However, the way this code word has been used has changed over time. Between June 2003 and December 2005, the ECB maintained its main refinancing rate at a level of $2 \%$, but frequently voiced its concern about inflation. Trichet (2006, p. 9) describes this strategy as follows: "Importantly, signalling vigilance proved instrumental in reaching a common understanding with the markets: the ECB, though observationally inactive, was at any time ready to start action." After December 2005, the ECB has tightened monetary policy in a number of consecutive steps. Interestingly, the keyword 'vigilance' continued to be used in ECB communication. However, the interpretation of 'vigilance' has changed as market participants now regarded 'vigilance' as an indicator of upcoming policy changes. ${ }^{7}$

Decision-making in the ECB Governing Council is often described as being 'collegial' (see Blinder 2007). Also the communication strategy of the ECB has been characterized as 'collegial'; in comparison to the Federal Reserve, the communication of individual central bankers of the ECB is less diverse (Ehrmann and Fratzscher 2007b). Still, there is quite some dispersion in ECB communication as will be discussed in more detail in Section 6, where we will also examine whether this dispersion affects the predictability of ECB interest rate decisions.

\section{Measuring ECB Communication}

Essentially three approaches have been developed in the literature to measure (the effects) of central bank communication. Starting with Kohn and Sack (2004), various studies have examined the effects of central bank communication events on the volatility of financial variables. The basic idea is that, if communications affect the returns on financial assets, the volatility of these returns should be higher on days of central bank communications, ceteris paribus, because the signals contain "news." Focusing on volatility makes it unnecessary to assign a direction to each statement. The most important weakness of this approach is that it cannot assess whether markets moved in the "right" direction (see Blinder et al. 2008 for a further discussion). In other words, the Kohn and Sack approach may establish that central bank communication creates news, but it is unable to determine whether it reduces noise.

In the second approach, communication is quantified in order to assess both the direction and magnitude of its effects on asset prices - and thus to determine to what

\footnotetext{
${ }^{6}$ A few central banks even provide quantitative guidance by publishing the numerical path of future policy rates that underlies their macroeconomic forecasts. Sweden and Iceland recently joined a small group that includes New Zealand and Norway in doing so. As Blinder et al. (2008) point out, announcing the path of the policy rate may complicate the central bank's decision-making process. It may also complicate communication with the public, which may not understand the conditional nature of the projection. In practice, the main concern holding back many central bankers is that such communications might be mistaken for commitments. If the projected developments do not materialize, the discrepancy between actual and previously projected policy might damage the central bank's credibility (Issing 2005).

7 According to Bloomberg, "ECB President Jean-Claude Trichet has used the word 'vigilant' to flag each of the six rate increases since late 2005" (Bloomberg News, 15 February 2007). Likewise, according to UBS: "Trichet has made a practice of effectively pre-announcing hikes at the prior meeting with the use of the key 'vigilant' phrase"” (UBS FX Trade and Research, 9 January 2007).
} 
extent communication has its intended effects. Communications must be classified according to their content and/or likely intention, and then coded on a numerical scale. Negative (positive) values are assigned to communications that are perceived as dovish (hawkish), and zero to those that appear to be neutral. Whereas some researchers restrict the coding to directional indications by using a scale between -1 and +1 (e.g., Jansen and De Haan 2005, Ehrmann and Fratzscher 2007b), others assign a finer grid that is at least suggestive of magnitude (Berger et al. 2006; Rosa and Verga 2007; Heinemann and Ullrich 2007, and Musard-Gies 2006), e.g., by coding statements on a scale from -2 to +2 . The most important weakness of the second approach is that it is necessarily subjective, and there may be misclassifications.

Recently, the Swiss KOF Institute started to publish its Monetary Policy Communicator for the Euro Area (KOF MPC) that provides a quantitative measure of ECB communication. ${ }^{8}$ It translates the ECB President's statements concerning risks to price stability as made during the monthly press conference into an index. By aggregating forward-looking statements concerning price stability, the KOF MPC contains information about the future path of ECB monetary policy. The KOF MPC is based on a coding of each introductory statement provided by Media Tenor, a media research institute. Media analysts read the text of the introductory statement of the monthly press conference sentence by sentence. Each sentence contains one or more statements, which are then coded. The coding is aggregated into the index by taking balances of the statements that reveal that the ECB sees upside risks to price stability and statements that reveal that the ECB sees downside risks to price stability, relative to all statements about price stability (including neutral). By construction, the values of the KOF MPC are restricted to be in the range of minus one to plus one. The larger a positive (negative) value of the KOF MPC, the stronger the ECB communicated that there are upside (downside) risks for price stability.

Finally, in the approach first suggested by Gürkaynak et al. (2005) and Gürkaynak (2005) and also implemented in Brand et al. (2006), indirect measures derived from financial market reactions are employed. Brand et al. (2006) make use of the timing details of the ECB's meeting day communications. The ECB announces its decisions at 1:45 P.M., without any explanatory statements, and then explains the decisions in detail in the press conference 45 min later. Because of that delay, the market reaction to the release of the decision can be separated from the market reaction to the forward-looking communication by using high-frequency data (see also Ehrmann and Fratzscher 2007a).

As pointed out before, one of the potential drawbacks of the second approach as described above is its subjectivity. Researchers have to code the communications by the ECB and that may lead to different results for various reasons. First, researchers may base their coding on different communication devices. Second, they may interpret the same information differently. ${ }^{9}$ To examine this issue in some detail, we have gathered various indicators that are all based on the second approach as outlined in the previous section. Figure 2 plot the indicators that were available.

\footnotetext{
${ }^{8}$ Available at: http://www.kof.ethz.ch/publications/indicators/communicator/en

${ }^{9}$ In the study by Berger et al. (2006), three different teams coded the introductory statements by the ECB President and this yielded some remarkable differences, especially with respect to the interpretation of comments referring to monetary aggregates.
} 

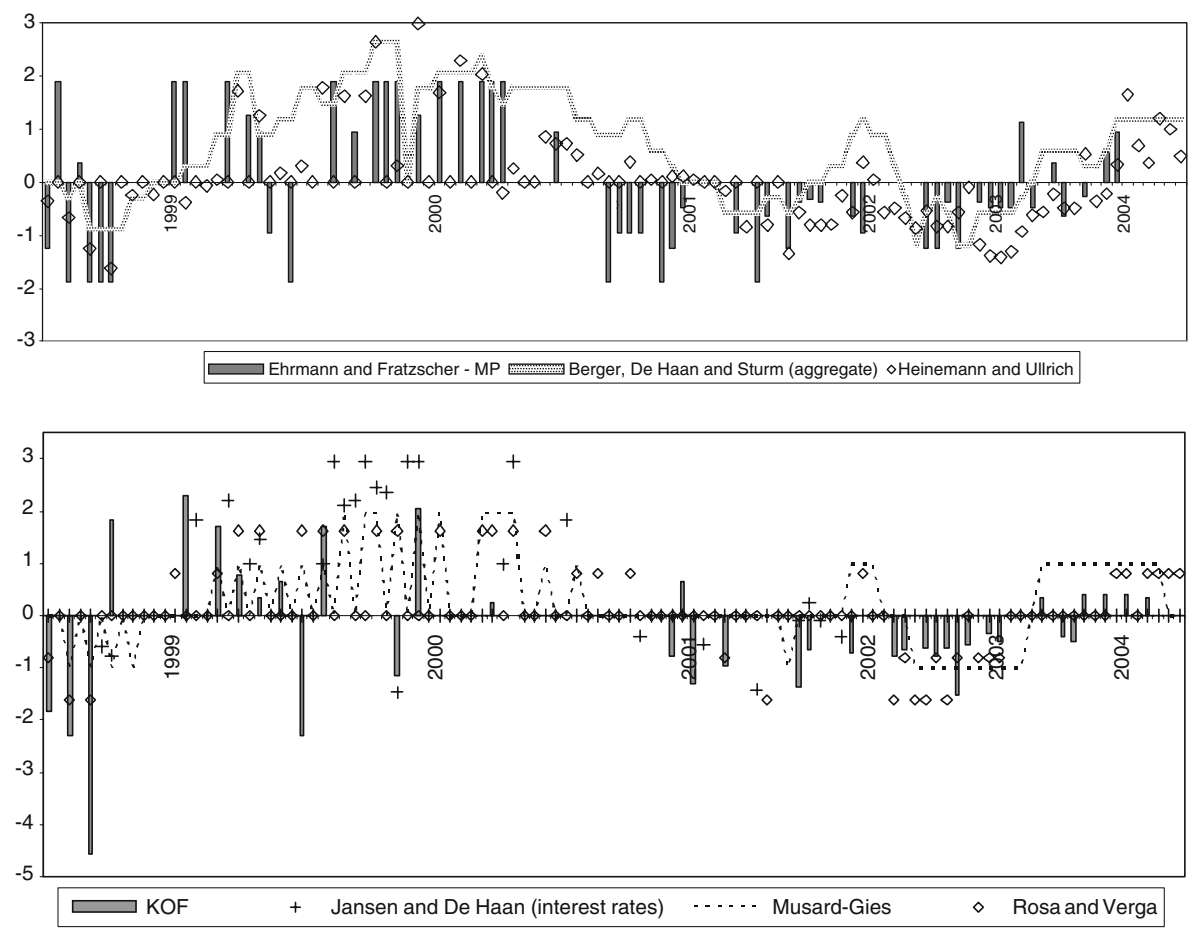

Fig. 2 Comparing various indicators of ECB communication

Apart from the Ehrmann-Fratzscher and the Jansen-DeHaan indicators, all indicators use the introductory statement by the ECB President during the press conference following the Governing Council meeting.

It becomes very clear that the various indicators differ substantially from each other. Still, the correlation among most indicators is quite high (Table 1). The exception is the KOF index that shows a remarkably low correlation with the other indicators. A possible reason is that the KOF index is more forward-looking and more focused on price stability than the other indicators.

\section{The Impact of ECB Communication on Financial Markets}

An important line of research focuses on the impacts of central bank communications on financial markets. The basic idea is that, if communications steer expectations, asset prices should react and policy decisions should become more predictable. Table 2 summarizes various recent studies on the financial market effects of ECB communication.

Table 2 shows that there is a broad consensus on many issues. First, ECB communication clearly moves financial markets. There is substantive evidence that various forms of ECB communication lead to more volatility. This holds true for short-term interest rates (Sebestyén and Sicilia 2005), the bond market (Andersson et al. 2006), the stock market (Andersson 2007), and the swap markets (Coffinet and Gouteron 2007). 


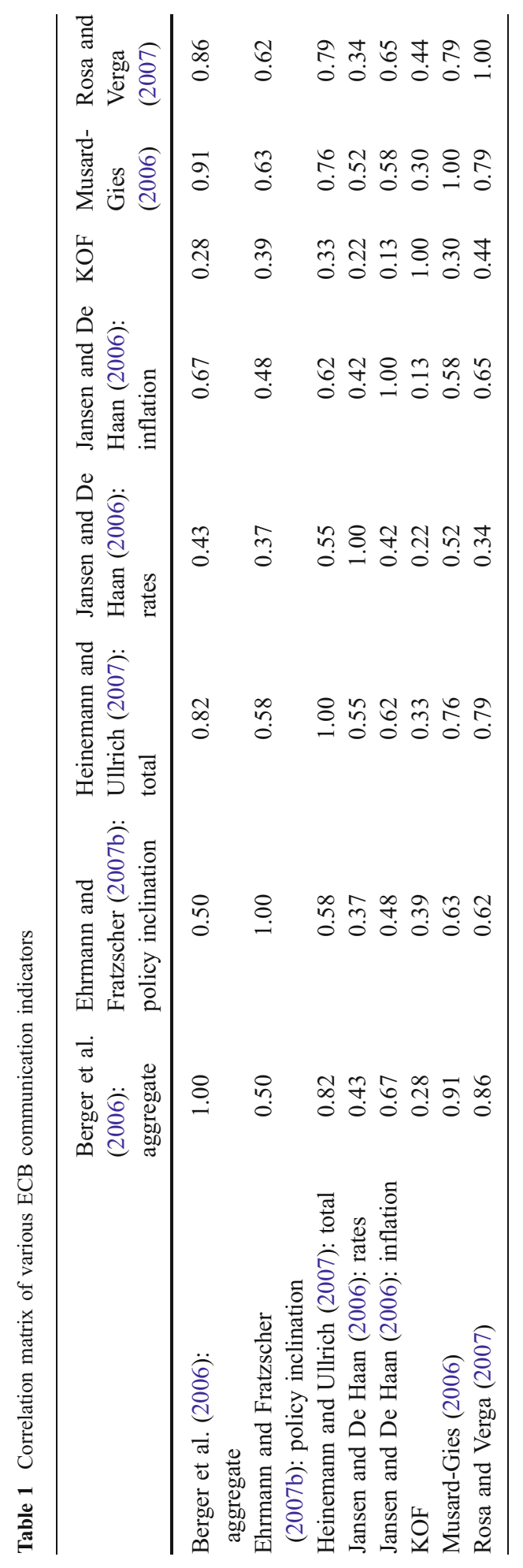




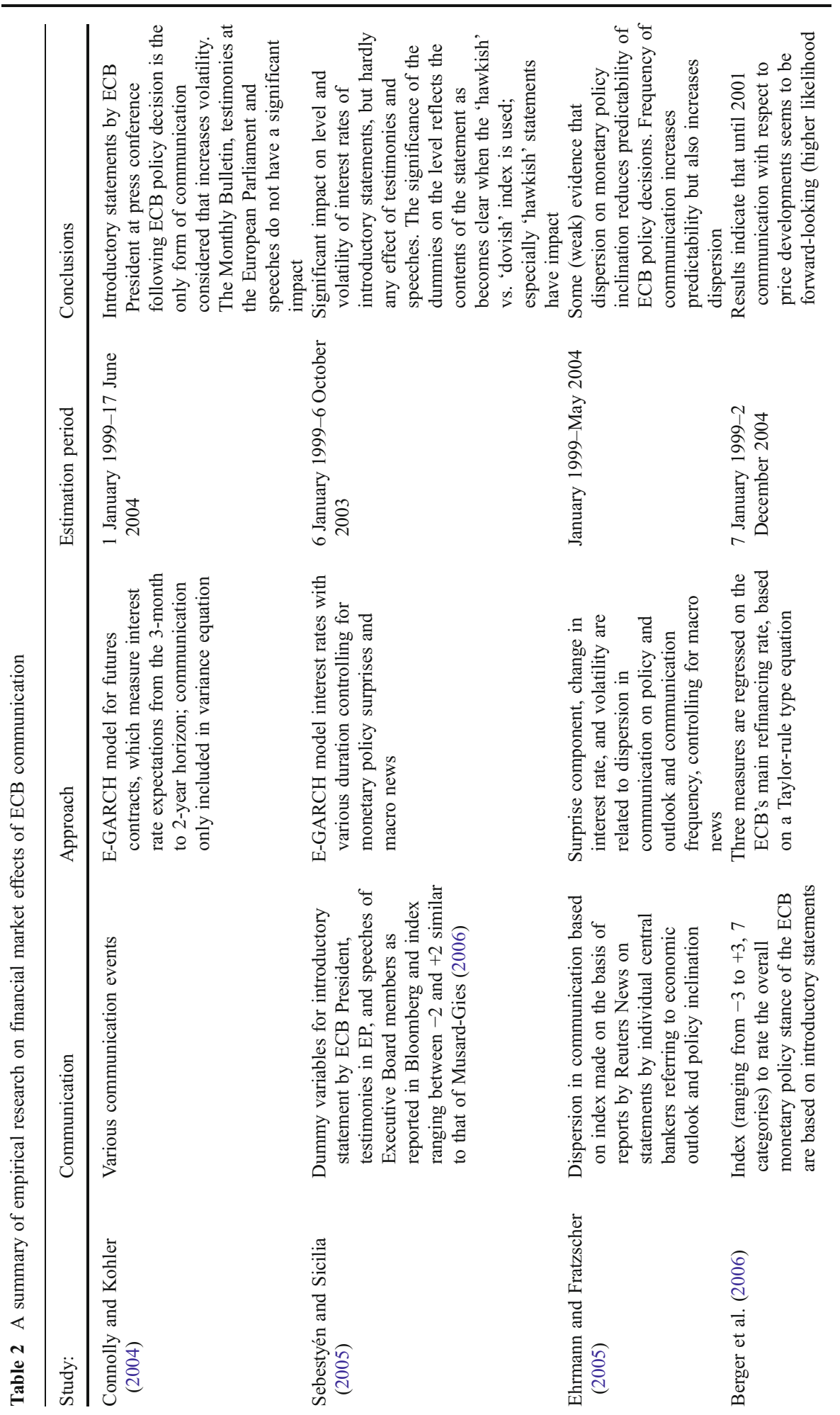



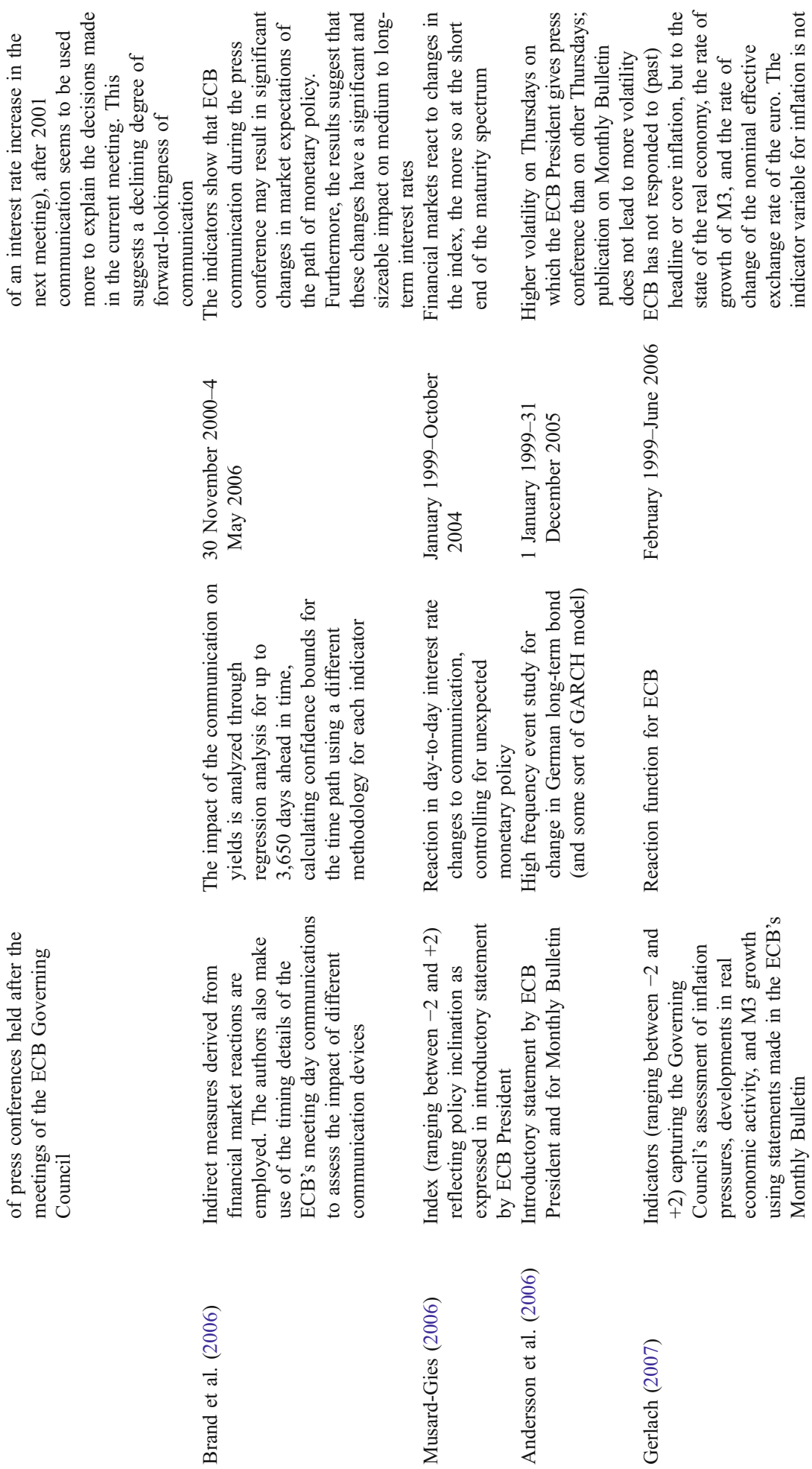


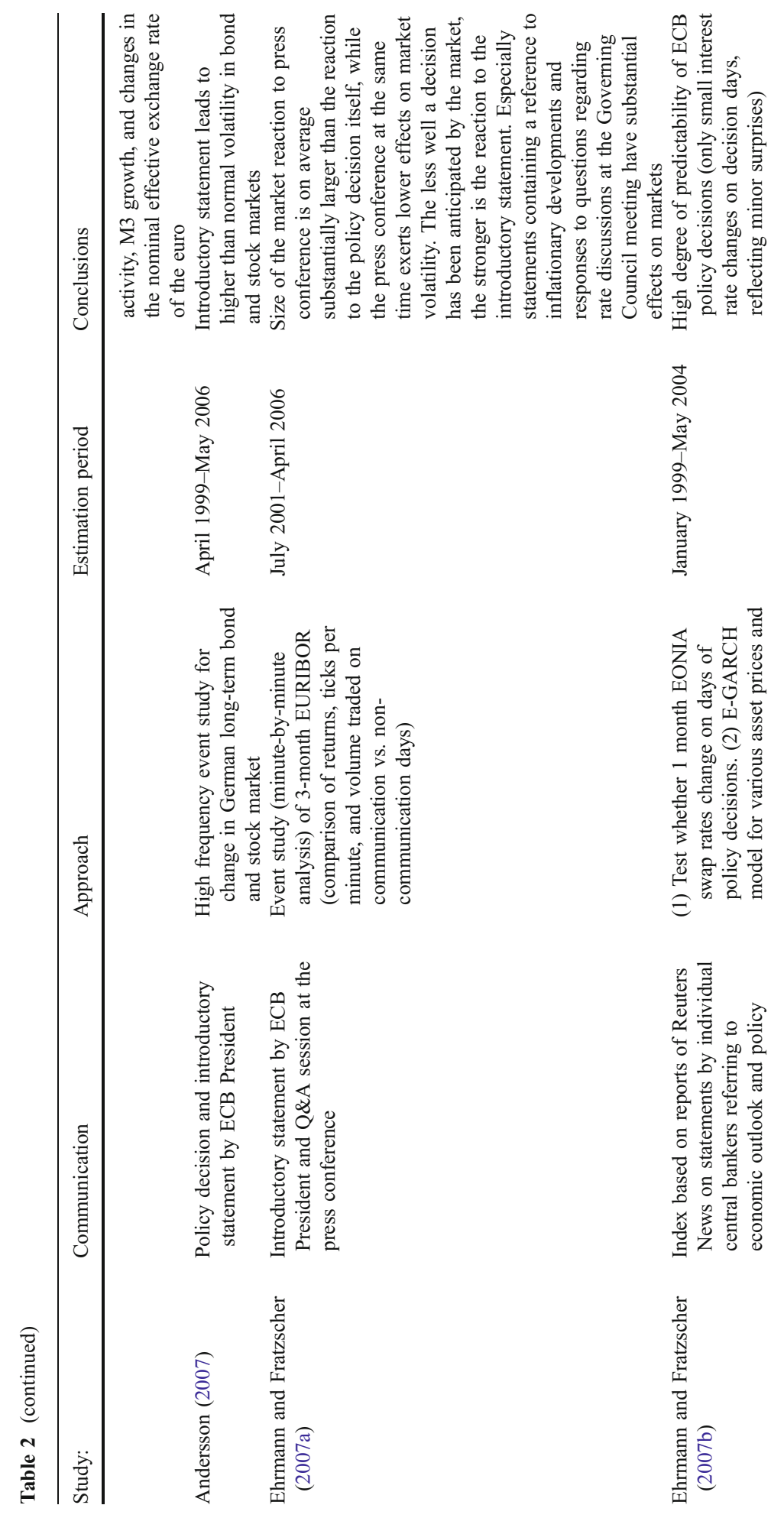




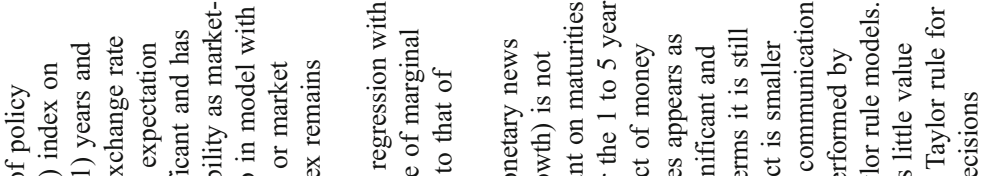

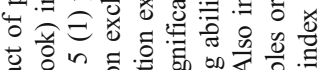

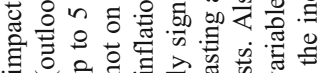

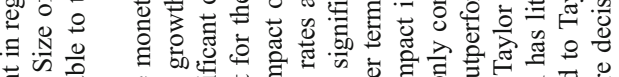

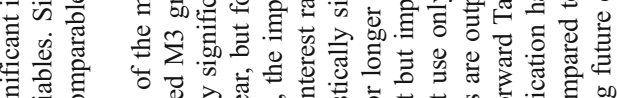

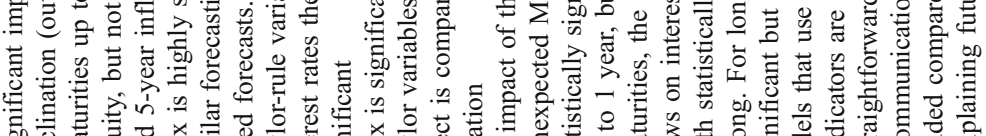

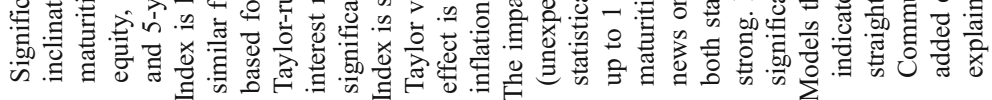
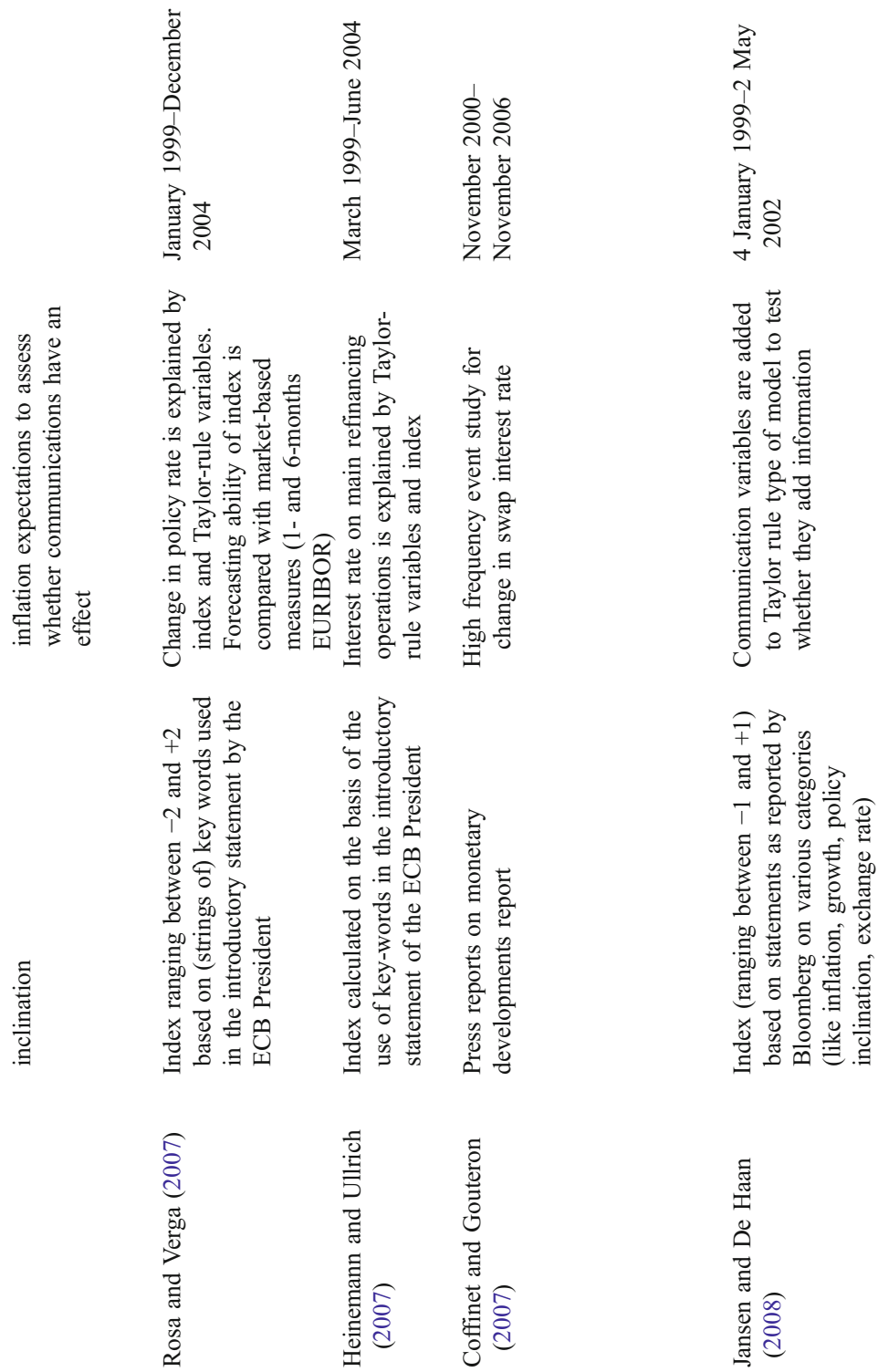
If more than one communication device is considered, the strongest effects are generally found for the introductory statements by the ECB President at the press conference following the Governing Council's meeting (Connolly and Kohler 2004 and Sebestyén and Sicilia 2005). Ehrmann and Fratzscher (2007a) analyze whether the press conferences provide additional information, beyond that explaining a given decision. If a policy decision contains all relevant information for market participants, markets should not show any systematic movement during press conferences. The separation of the release of the decision from its explanation allows separating the effect of monetary policy decisions from the accompanying communication. These authors find that the size of the market reaction to press conference is, on average, substantially larger than the reaction to the policy decision itself, while the press conference at the same time exerts lower effects on market volatility. The market reaction to the press conference is related to the characteristics of the decision: the less well a decision has been anticipated by the market, the stronger is the reaction to the introductory statement. Especially statements containing a reference to inflationary developments and responses to questions regarding interest rate discussions at the Governing Council meeting have substantial effects on markets.

In conclusion, studies focusing on volatility suggest that financial markets clearly respond to ECB communication. However, as pointed out before, studies following this approach cannot assess whether markets moved in the direction as intended by the central bank.

Second, studies that have coded ECB communication yield evidence that communication moves financial markets in the intended direction. For instance, Ehrmann and Fratzscher (2007b) find that statements suggesting tightening lead to higher rates, while statements suggesting easing lead to lower rates. Statements on monetary policy inclinations move interest rates by $1.5-2.5$ basis points. MusardGies (2006) finds similar results, although the short end of the yield curve reacts more sharply to statements than the long end. Using a different approach, Brand et al. (2006) find that the effect of the ECB's communications is particularly sizable at the long end of the yield curve. In contrast, Brière and Ielpo (2007) conclude that ECB policy rate announcements affect only the very short segment of the curve. These authors argue that the main reason why they find that long-term rates are hardly affected is that they better control for the influence of the US economy. ${ }^{10}$

Third, there is much evidence suggesting that ECB communications increase the predictability of interest decisions by the Governing Council. ${ }^{11}$ A good example of a study yielding this outcome is Rosa and Verga (2007). These authors conclude that the forecasting ability of communication by the ECB (measured on the basis of the

\footnotetext{
${ }^{10}$ Other studies capture the US influence by including both European and American economic announcements in the regression used to explain European interest rates. However, the US yield-curve changes even in the absence of any economic announcements in the US. The authors therefore analyze the influence of the entire American yield curve on European rates.

${ }^{11}$ Ehrmann and Fratzscher (2007b) examine whether 1 month EONIA swap rates change on days of policy decisions, thereby testing whether policy decisions were expected. This, however, does not provide direct evidence that the predictability is the outcome of effective communication.
} 
introductory statements of the ECB President) is similar to the one implied by market-based measures of monetary policy expectations.

However, there is less agreement as to whether communication adds information compared to the information contained by variables typically included in a Taylorrule model. ${ }^{12}$ In other words, it is not entirely clear to what extent ECB communication adds information that helps to predict interest rate decisions. Heinemann and Ullrich (2007) find that their communication index, based on the wording of the introductory statements by the ECB President at the press conference following Governing Council meetings, adds information not provided by Taylorrule variables. Also Rosa and Verga (2007) conclude that words and data on macroeconomic variables are essentially complements, rather than substitutes. However, Jansen and De Haan (2008) conclude that during the first years of the EMU straightforward Taylor rule models outperform models that only use communication indicators. More importantly, the information content of the statements was mainly a reflection of macroeconomic developments. If these authors control for this effect, communication has little value added for explaining future decisions. In other words, communication and macroeconomic variables are substitutes instead of complements.

To sum up and coming back to the questions that we raised in the Introductioni.e., has ECB communication affected interest rates and has it increased the predictability of policy decisions? - the empirical evidence suggests that the answer to both questions is a qualified 'yes'.

However, impact on financial markets and high predictability of policy decisions are necessary but not sufficient conditions for successful and effective communication as communication policy should also aim at anchoring and guiding market expectations over the medium to long run (Issing 2005). As the main objective of the ECB is price stability, an important issue is to what extent communication can help anchoring inflation expectations. According to ECB President Trichet, the upward move in Euro area inflation expectations in late 2003 - when the policy rate was being held at an exceptionally low level-was reversed by the ECB's communication becoming increasingly alert ('vigilant') to the inflation risks generated by the move in inflation expectations: "stability in long term inflation expectations was restored without engineering policy actions" (Trichet 2005).

Only three studies that we are aware of have examined the impact of the ECB's communication on inflation expectations. Ehrmann and Fratzscher (2007b, c) examine the impact of communication on 5-year inflation expectations derived from indexed bonds and find that their measures do not have a significant impact on inflation expectations. Jansen and De Haan (2007b) find evidence that communication by the ECB regarding risks to price stability (measured by the frequency and

\footnotetext{
12 As Bernanke and Boivin (2003) point out, most empirical analyses of monetary policy have been confined to frameworks in which the central bank is implicitly assumed to exploit only a limited amount of information, like in the Taylor-rule model. In practice, the central banks' approach to data analysis typically mixes the use of large macro-econometric models, smaller statistical models, heuristic and judgmental analyses, and informal weighting of information from diverse sources. One way of interpreting central bank communication may be that it summarizes the central bank's assessment of all the information it employs. In that case, models using central bank communication should outperform those that rely only on a limited number of macro variables.
} 
strength of the key word 'vigilance') between June 2003 and December 2005-a period during which the ECB did not change its policy rates-reduced highfrequency inflationary expectations slightly in the second half of 2005, when a change in the ECB's policy stance became increasingly likely. To some extent, their results lend support to Trichet's (2005) claim that communication has helped stabilize inflation expectations without a policy change. However, the reported impact is quite small so that it is clear that other factors also played a crucial role in stabilizing these expectations. Furthermore, the impact is only significant for the period when an interest rate hike became more likely. In other words, communication works best when supported by (a credible threat of) deeds.

\section{New Evidence on the Impact of Communication Dispersion on the Predictability of ECB Policy Decisions ${ }^{13}$}

In the previous section we have shown that ECB communication has enhanced the predictability of policy decisions. Still, there is a danger that too many disparate voices might confuse rather than enlighten the public-especially if the messages appear to conflict. If done poorly, uncoordinated group communication might actually lower, rather than raise, the signal-to-noise ratio. We have examined this issue using a content analysis of reports from the news-wire Bloomberg. We have collected reports on comments by leading euro area central bankers, such as members of the ECB's Executive Board and the presidents of national central banks. ${ }^{14}$ We focus on ECB statements on the main refinancing rate, the outlook for euro area inflation, and the outlook for euro area economic growth. Per topic, we classify each comment on a ternary scale $(-1,0,+1)$. For example, statements suggesting a tightening of monetary policy are coded +1 , whereas statements hinting at interest rate cuts are coded -1 . We measure dispersion in communication by computing the standard deviation of the coded statements. The event window is always equal to the period between two subsequent ECB interest rate meetings. The sample period is 6 May 1999 to 2 May 2002. This period is interesting as both the ECB and financial markets had to learn how to deal with communication by a newly created international organization. As shown in Fig. 3, notably ECB statements on the outlook for inflation and economic growth were inconsistent, with the degree of inconsistency somewhat increasing over time.

We evaluate the effects of dispersion on predictability by using survey data on interest rate expectations. These expectations are taken from the Reuters poll of forecasters. The use of these data instead of market-based expectations allows us to examine the impact of communication dispersion on market uncertainty as reflected in the dispersion of the views of the forecasters. Before each ECB interest rate decision, Reuters polls key economists on their views on the main refinancing rate after the upcoming meeting. We study the effects of inconsistent communication using three characteristics of the survey data. First, we examine whether the absolute

\footnotetext{
13 This part of the paper is based on an unpublished note written together with David-Jan Jansen.

14 The dataset is described in more detail in Jansen and De Haan (2005).
} 
i) Main refinancing rate

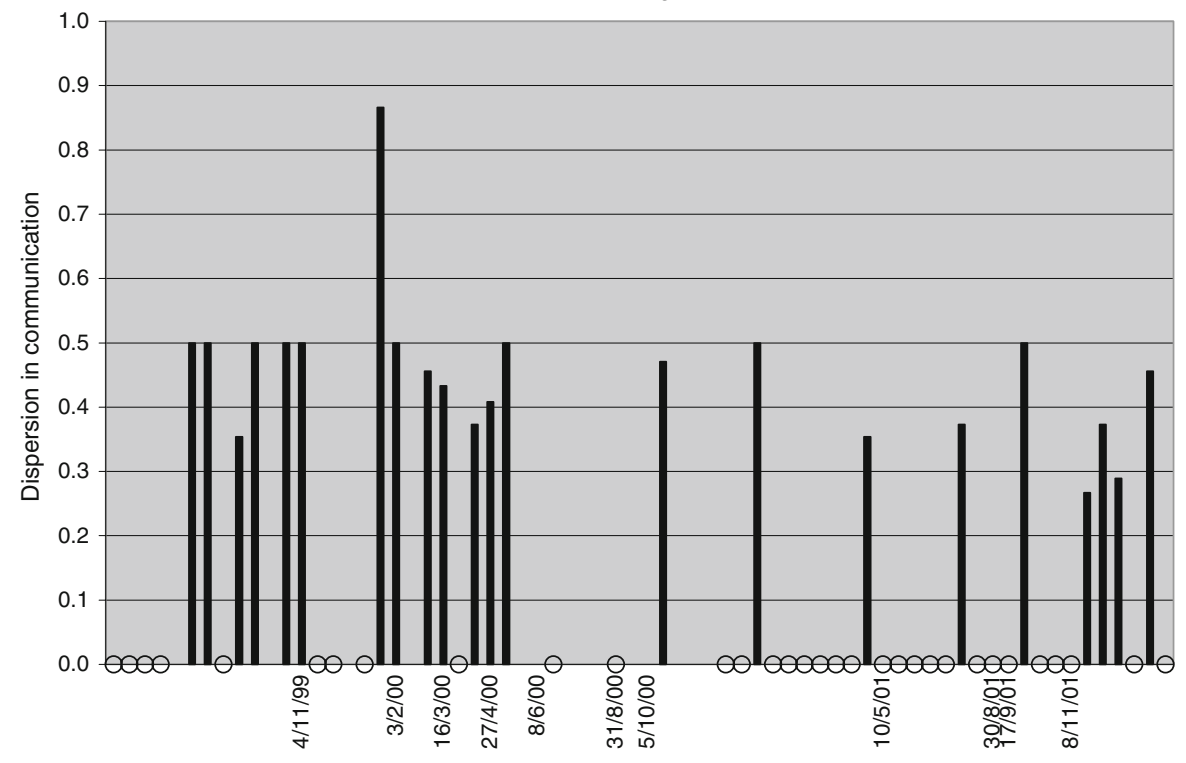

ii) Euro area inflation

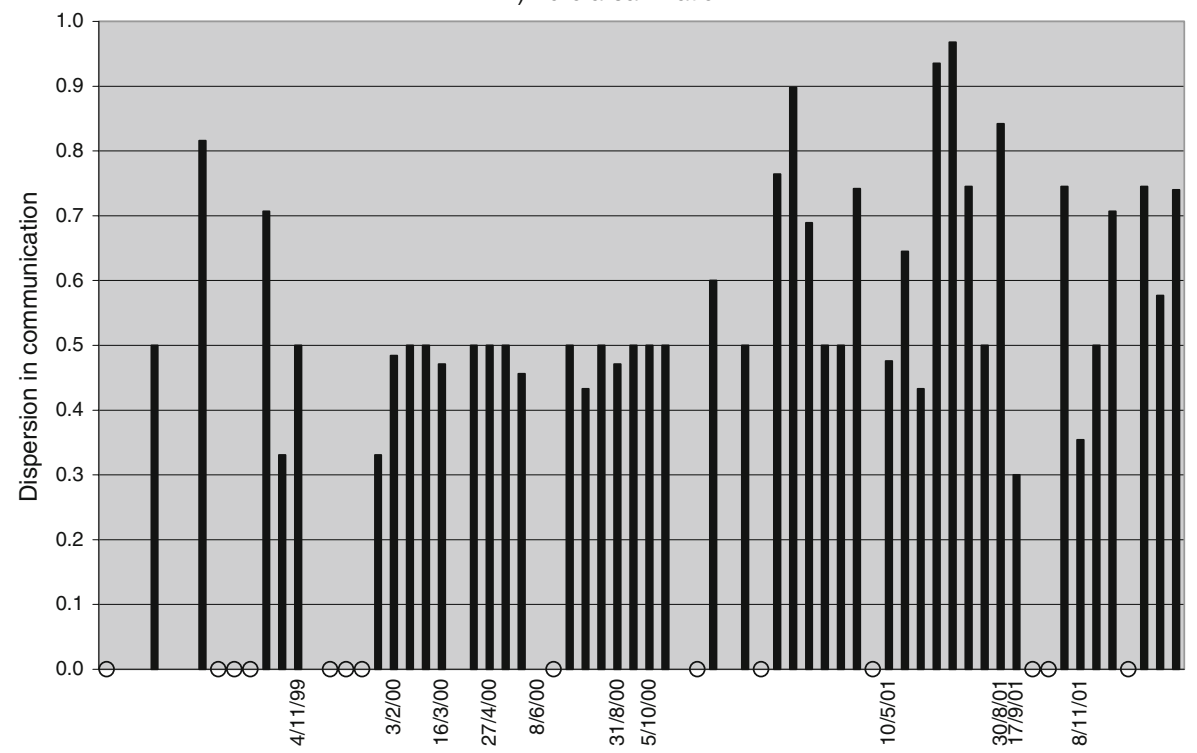

Fig. 3 Dispersion in comments by euro area central bankers. Note: The figures show the degree of dispersion in comments on $i$ the ECB main refinancing rate, $i i$ euro area inflation and iii euro area economic growth. Dispersion is measured as the standard deviation of the coded statements. The sample period is 6 May 1999 to 2 May 2002. The dates correspond to the occurrence of ECB interest rate changes (DD/MM/YY). The circles on the $x$-axis indicate that there was more than one comment on a specific topic during the event window, but no inconsistency between the comments 
iii) Euro area economic growth

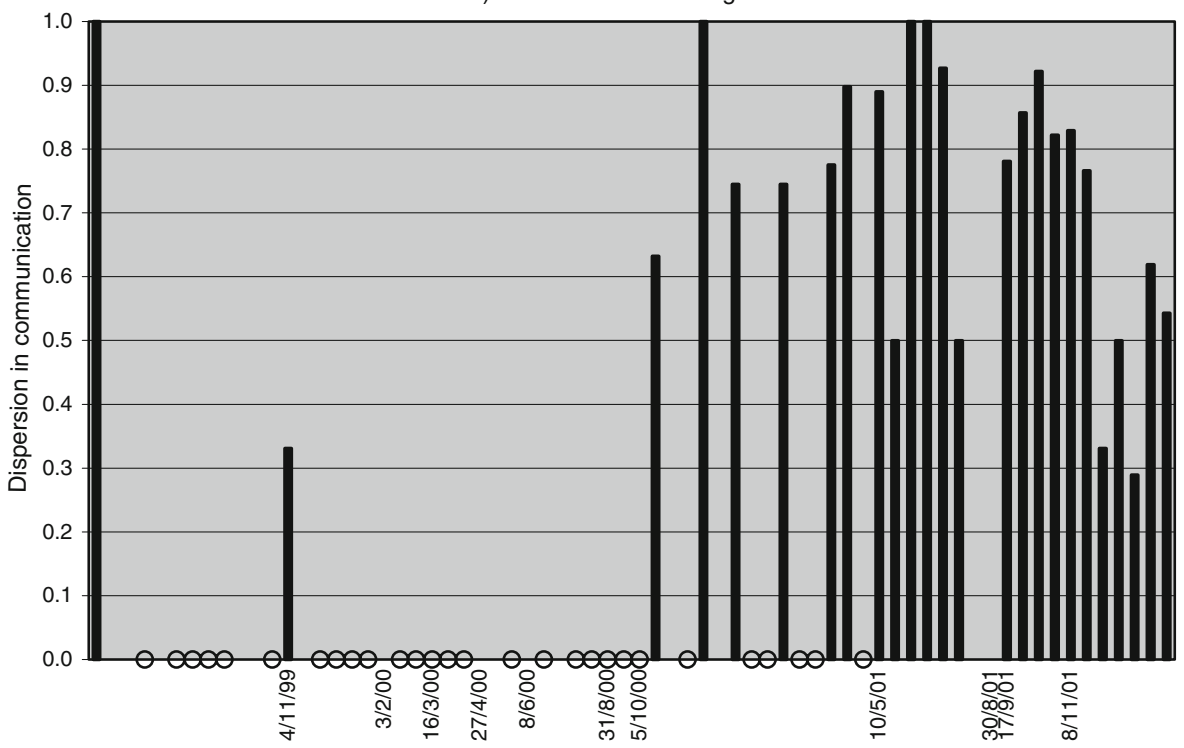

Fig. 3 Continued.

difference between the actual decision and the median of the Reuters survey is positively related to dispersion in communication. ${ }^{15}$ Second, we study whether the percentage of incorrect predictions is positively related to dispersion. Finally, we examine whether the standard deviation of the expected interest rates is positively related to dispersion. ${ }^{16}$

In all three cases, following Ehrmann and Fratzscher (2005) we rely on a tobit specification to account for the fact that the dependent variables are censored. In the first and third case, the censoring is at the value zero, in the second case, the dependent variable is censored at zero and one. Finally, we account for the fact that communication is not the only factor that influences predictability. We do this by using the standard deviation of a daily series of 1-month Euribor rates in the week before the one in which the interest rate decision is made to control for macroeconomic uncertainty. ${ }^{17}$

Table 3 shows tobit estimation results where the dependent variable is either the absolute prediction error (column 1), the fraction of incorrect predictions (column 2) or the standard deviation of expected interest rates (column 3).

\footnotetext{
${ }^{15}$ We have also used the mean instead of the median of the survey and the results are qualitatively very similar.

${ }^{16}$ As pointed out by one of the referees, this implies that we do not separate volatility in asset prices from moves (jumps) in asset prices (see Jondeau et al. 2006 for a further discussion). We leave this issue for future research.

${ }^{17}$ We also estimated specifications with a linear trend as, over the years, the ECB may have become more predictable. This did not affect the results.
} 
Table 3 Dispersion in ECB communication and the predictability of interest rate decisions

\begin{tabular}{|c|c|c|c|}
\hline & \multicolumn{3}{|l|}{ Dependent variable: } \\
\hline & $\begin{array}{l}\text { (1) } \\
\text { Absolute prediction } \\
\text { error (median) }\end{array}$ & $\begin{array}{l}(2) \\
\text { Fraction of } \\
\text { incorrect predictions }\end{array}$ & $\begin{array}{l}\text { (3) } \\
\text { Standard deviation } \\
\text { of expected rates }\end{array}$ \\
\hline \multicolumn{4}{|l|}{ Dispersion in comments on } \\
\hline Main refinancing rate & $0.06(0.29)$ & $-0.01(0.25)$ & $0.02(0.04)$ \\
\hline Euro area inflation & $0.44^{\mathrm{a}}(0.22)$ & $0.41^{\mathrm{b}}(0.20)$ & $0.11^{\mathrm{c}}(0.03)$ \\
\hline Euro area economic growth & $0.07(0.18)$ & $0.17(0.15)$ & $0.03(0.03)$ \\
\hline Standard deviation 1-month Euribor & $3.88^{\mathrm{b}}(1.84)$ & $4.50^{\mathrm{b}}(1.79)$ & $0.88^{\mathrm{c}}(0.31)$ \\
\hline Constant & $-0.67^{\mathrm{b}}(0.17)$ & $-0.28^{\mathrm{b}}(0.13)$ & $-0.04^{\mathrm{b}}(0.02)$ \\
\hline $\mathrm{Chi}^{2}$ LR-test & 6.1 & $12.2^{\mathrm{b}}$ & $19.4^{\mathrm{c}}$ \\
\hline Number of observations & 65 & 65 & 65 \\
\hline Percentage of censored observations & 70.5 & 43.1 & 41.5 \\
\hline
\end{tabular}

Standard errors in parenthesis. The sample period is 6 May 1999 to 2 May 2002. All results use robust Huber-White standard-errors

${ }^{a}$ Significance at the $10 \%$ level

${ }^{\mathrm{b}}$ Significance at the $5 \%$ level

${ }^{\mathrm{c}}$ Significance at the $1 \%$ level

We find that dispersion on the inflation outlook influences predictability as measured by the absolute prediction error, while inconsistencies in statements on the main refinancing rate and the outlook for economic growth are not related to the absolute prediction error (column 1). We also find a positive relationship between dispersion in comments on inflation and the degree of incorrect interest rate predictions (column 2). The marginal effect in this case is equal to $0.21 \quad(p=0.03)$ which implies a sizeable effect of dispersion on predictability. Finally, there is a strong indication that dispersion leads to higher levels of uncertainty as the coefficient for the variable measuring dispersion in inflation comments is highly significant (column 3). The marginal effect in this case is equal to $0.07(p=0.00)$.

\section{Conclusions}

A substantial body of research has examined the impact of ECB communication on financial markets. The basic underlying idea of this research is that, if communications steer expectations, asset prices should react and policy decisions should become more predictable. Theoretically, central banks communications may affect asset prices if one or more of the following conditions hold: non-rational expectations, absence of policy rules and credibility, and asymmetric information. Even though there are good reasons why communication may be beneficial, it is by no means clear what constitutes an optimal communication strategy.

The ECB mainly relies on four communication devices. The ECB's most important communication device is the President's introductory statement at the monthly press conference in which he reports on the decisions taken by the ECB's Governing Council. Other instruments used are: the Monthly Bulletin, testimonies before the European Parliament, and speeches and interviews of individual members of the Governing Council. 
Various studies have shown that ECB communication moves financial markets. There is substantive evidence that various forms of ECB communication lead to more volatility. This holds true for short-term interest rates, the bond market, the stock market, and the swap markets. If more than one communication device is considered, the strongest effects are generally found for the introductory statements by the ECB President at the press conference following the Governing Council's meeting. However, studies focusing on volatility cannot assess whether markets moved in the intended direction. To analyze whether this is the case, researchers have coded ECB communications. Studies using this approach yield evidence that communications generally move financial markets in the intended direction. There is also substantive evidence that ECB communications increase the predictability of interest decisions by the Governing Council. However, there is less agreement as to whether communication adds information compared to the information contained by variables typically included in a Taylor-rule like model. In other words, it is not entirely clear to what extent ECB communication adds information that helps to predict interest rate decisions.

Even though predictability and market impact of communication are necessary, they are not sufficient conditions for successful and effective communication as communication policy should also aim at anchoring and guiding market expectations over the medium to long run. Some recent research suggests that communication by the ECB regarding risks to price stability reduced high-frequency inflationary expectations slightly. However, the reported impact is quite small so that it is clear that other factors also played a crucial role in stabilizing these expectations. Furthermore, the impact is only significant for the period when an interest rate hike became more likely. In other words, communication works best when supported by (a credible threat of) deeds.

Finally, we discuss the consequences of the fact that ECB officials often gave contrasting signals to market participants. These diverging signals were related to various aspects of monetary policy, such as the policy inclination, or the economic outlook. It is likely that this dispersion affects the ability of market participants to correctly predict monetary policy decisions. Using statements by euro area central bankers as reported by Bloomberg, we find that inconsistent communication on the inflation outlook coincides with greater uncertainty regarding upcoming ECB interest rate decisions. Dispersion in communication is also positively related to prediction errors. Our results, therefore, suggest that inconsistencies in central bank communication matter. When different central bankers convey diverging information, uncertainty about upcoming decisions increases. In addition, agents make less accurate predictions. The policy implication is that central bankers should take care that their statements are consistent.

Acknowledgements I like to thank David-Jan Jansen and Christiaan Burggraaff for their support and participants in The Political Economy of International Organizations conference, Ascona, 3-8 February 2008 , as well as four referees for their comments.

Open Access This article is distributed under the terms of the Creative Commons Attribution Noncommercial License which permits any noncommercial use, distribution, and reproduction in any medium, provided the original author(s) and source are credited. 


\section{References}

Amato, J. D., Morris, S., \& Shin, H. S. (2002). Communication and monetary policy. Oxford Review of Economic Policy, 18(4), 495-503.

Andersson, M. (2007). Using intraday data to gauge financial market responses to Fed and ECB monetary policy decisions. ECB working paper 726.

Andersson, M., Hansen, L. J., \& Sebestyén, S. (2006). Which news moves the Euro area bond market? ECB working paper 631 .

Balduzzi, P., Elton, E. J., \& Green, T. C. (2001). Economic news and the yield curve: Evidence from the U.S. Treasury market. Journal of Financial and Quantitative Analysis, 36(4), 523-543.

Berger, H., De Haan, J., Sturm, J.-E. (2006). Does money matter in the ECB strategy? New evidence based on ECB communication. CESifo working paper 1652.

Bernanke, B. (2004). Fedspeak, remarks at the meetings of the American Economic Association, San Diego: The Federal Reserve Board. http://www.federalreserve.gov/boarddocs/speeches/2004/ 200401032/default.htm Accessed 25 June 2007.

Bernanke, B., \& Boivin, J. (2003). Monetary policy in a data-rich environment. Journal of Monetary Economics, 50(3), 525-546.

Blinder, A. S. (2007). Monetary policy by committee: why and how. European Journal of Political Economy, 23(1), 106-123.

Blinder, A. S., Ehrmann, M., Fratzscher, M., De Haan, J., Jansen, D. (2008). Central bank communication and monetary policy: A survey of theory and evidence. Journal of Economic Literature, in press.

Brand, C., Buncic, D., Turunen, J. (2006). The impact of ECB monetary policy decisions and communication on the yield curve. ECB working paper 657.

Brière, M., Ielpo, F. (2007). Yield curve reaction to macroeconomic news in Europe: Disentangling the US influence. Solvay Business School working paper 07/38.

Coffinet, J., Gouteron, S. (2007). Euro area market reactions to the monetary developments press release. ECB working paper 792.

Connolly, E., \& Kohler, M. (2004). News and interest rate expectations: A study of six central banks. In C. Kent, \& S. Guttman (Eds.), The future of inflation targeting (pp. 108-134). Sydney: Reserve Bank of Australia.

Conrad, C., \& Lamla M. J. (2007). The high-frequency response of the EUR-US Dollar exchange rate to ECB monetary policy announcements. Working paper 07-174, KOF Swiss Economic Institute, ETH Zurich.

Ehrmann, M., \& Fratzscher, M. (2005). How should central banks communicate? ECB working paper 557.

Ehrmann, M., \& Fratzscher, M. (2007a). Explaining monetary policy decisions in a press conference. ECB working paper 767 .

Ehrmann, M., \& Fratzscher, M. (2007b). Communication by central bank committee members: Different strategies, same effectiveness. Journal of Money, Credit, and Banking, 39(2-3), 509-541.

Ehrmann, M., \& Fratzscher, M. (2007c). The timing of central bank communication. European Journal of Political Economy, 23(1), 124-145.

Faust, J., \& Svensson, L. E. O. (2001). Transparency and credibility: Monetary policy with unobservable goals. International Economic Review, 42(2), 369-397.

Fratzscher, M. (2004). Communication and exchange rate policy. ECB working paper 363.

Geraats, P. (2002). Central bank transparency. The Economic Journal, 112(483), 532-565.

Gerlach, S. (2007). Interest rate setting by the ECB, 1999-2006: Words and deeds. International Journal of Central Banking, 3(3), 1-46.

Gürkaynak, R. S. (2005). Using federal funds futures contracts for monetary policy analysis. Federal Reserve Board, Finance and Economic discussion series 2005-29.

Gürkaynak, R. S., Sack, B., \& Swanson, E. T. (2005). Do actions speak louder than words? The response of asset prices to monetary policy actions and statements. International Journal of Central Banking, 1 (1), 55-93.

Heinemann, F., \& Ullrich, K. (2007). Does it pay to watch central bankers lips? The information content of ECB wording. Swiss Journal of Economics and Statistics, 143(2), 155-185.

Issing, O. (2005). Communication, transparency, accountability-monetary policy in the twenty-first century. Federal Reserve Bank of St. Louis Review, 87(2), 65-83.

Jansen, D., \& De Haan, J. (2005). Talking heads: The effects of ECB statements on the Euro-Dollar exchange rate. Journal of International Money and Finance, 24(2), 343-361. 
Jansen, D., \& De Haan, J. (2006). Look who's talking: ECB communication during the first years of EMU. International Journal of Finance and Economics, 11(3), 219-228.

Jansen, D., \& De Haan, J. (2007a). Were verbal efforts to support the Euro effective? A high-frequency analysis of ECB statements. European Journal of Political Economy, 23(1), 245-259.

Jansen, D., \& De Haan, J. (2007b). The importance of being vigilant: Has ECB communication influenced Euro area inflation expectations? CESifo working paper 2154.

Jansen, D., \& De Haan, J. (2008). Does ECB communication help in predicting its interest rate decisions? Applied Economics, in press.

Jondeau, E., Poon, S., \& Rockinger, M. (2006). Financial modeling under non-Gaussian distributions. London: Springer.

Kahnemann, D. (2003). Maps of bounded rationality: Psychology for behavioral economics. American Economic Review, 93(5), 1449-1475.

King, M. (2005). Monetary policy: Practice ahead of theory. Mais Lecture, delivered at Cass Business School, London. http://www.bankofengland.co.uk/publications/speeches/2005/speech245.pdf Accessed 25 June 2007.

Kohn, D. L., \& Sack, B. (2004). Central bank talk: Does it matter and why? In Macroeconomics, monetary policy, and financial stability pp. 175-206. Ottawa: Bank of Canada.

Musard-Gies, M. (2006). Do ECB's statements steer short-term and long-term interest rates in the eurozone. The Manchester School, 74, 116-139 (supplement).

Poole, W. (2001). Expectations. Federal Reserve Bank of St. Louis Review, 83(1), 1-10.

Romer, C. D., \& Romer, D. H. (2000). Federal reserve information and the behavior of interest rates. American Economic Review, 90(3), 429-457.

Rosa, C., \& Verga, G. (2007). On the consistency and effectiveness of central bank communication: Evidence from the ECB. European Journal of Political Economy, 23(1), 146-175.

Sebestyén, S., \& Sicilia, J. (2005). Is the external communication of the European Central Bank effective? Mimeo.

Siklos, P., \& Bohl, M. (2006). Policy words and policy deeds: The ECB and the Euro. Bank of Finland discussion paper $2 / 2006$.

Swanson, E. T. (2006). Federal reserve transparency and financial market forecasts of short-term interest rates. Journal of Money, Credit, and Banking, 38(3), 791-819.

Trichet, J. C. (2005). Monetary policy and 'credible alertness'. Intervention at the panel discussion "Monetary Policy Strategies: A Central Bank Panel", at the Symposium sponsored by the Federal Reserve Bank of Kansas City, Jackson Hole, Wyoming, 27 August 2005. http://www.ecb.int/press/ key/date/2005/html/sp050827.en.html Accessed 25 June 2007.

Trichet, J. C. (2006). Activism and alertness in monetary policy. Lecture at the conference on 'Central banks in the 21st Century' organised by the Banco de Espana, 8 June. http://www.ecb.int/press/key/ date/2006/html/sp060608_1.en.html Accessed 11 August 2008.

Woodford, M. (2005). Central-bank communication and policy effectiveness. In The Greenspan era: Lessons for the future (pp. 399-474). Kansas City: Federal Reserve Bank of Kansas City. 